\title{
Pengaruh Struktur Modal dan Faktor Eksternal terhadap Nilai Perusahaan (Studi pada PT. Bank Central Asia, Tbk)
}

\author{
Muhammad Fuad ${ }^{1{ }^{*}}$, Ayu Wandari ${ }^{2)}$ \\ ${ }^{1)}$ Fakultas Ekonomi, Universitas Samudra \\ e-mail:muhammadfuad@unsam.ac.id \\ ${ }^{2)}$ Fakultas Ekonomi, Universitas Samudra \\ e-mail: ayuwandari56@gmail.com
}

\begin{abstract}
The research aims to analyze the influence of capital structure and external factors on firm value. Object of research at PT. Bank Central Asia, Tbk, with the 20072016 financial periods. Capital structure is represented by debt to equity ratio (DER); external factors tested include inflation, interest rates and exchange rates; as well, company value is measured using price to book value (PBV). Data analysis method uses multiple linear regression (MRA). Four partial hypotheses were tested using t-test, while one simultaneous hypothesis was tested using F-test. The regression analysis results stated that capital structure, inflation and exchange rate had a negative influence on firm value; while interest rates have a positive influence on firm value. Furthermore, capital structure has a dominant influence on firm value. Hypothesis test results showed that all independent variables have an insignificant effect on firm value as dependent variables, both partially and simultaneously. The coefficient of determination showed the independent variables analyzed in this research model contribute relatively high in explaining the variance that occurs in the firm value of PT Bank Central Asia, Tbk.
\end{abstract}

Keywords: Capital structure, inflation, interest rate, exchange rate, firm value.

\section{PENDAHULUAN}

Tujuan utama bagi sebuah perusahaan adalah bagaimana memaksimalkan nilai perusahaan.Khususnya perusahaan yang telah terbuka atau listing di Bursa Efek Indonesia, nilai perusahaan dicerminkan oleh harga sahamnya (Husnan \& Pudjiastuti, 2012).Semakin tinggi harga saham maka menunjukkan semakin tinggi nilai perusahaan yang bersangkutan.Nilai perusahaan juga merupakan indikator utama yang dibutuhkan investor dalam proses pengambilan keputusan investasinya (Fuad dkk., 2017). Harga saham yang semakin tinggi juga bisa diartikan bahwa semakin tingginya tingkat kesejahteraan yang dinikmati oleh pemegang saham (stockholders' wealth). Dengan demikian, nilai perusahaan yang tinggi akan menciptakan dan kepercayaan tinggi dari pasar, tidak hanya berkaitan dengan kinerja perusahaan saat ini, tetapi juga sentimen positif mengenai prospek masa depan dari perusahaan yang bersangkutan (Brigham \& Houston, 2013).

Sebagai salah satu perusahaan yang listing di pasar modal, PT. Bank Central Asia, Tbk. juga perlu memperhitungkan nilai perusahaan yang diraihnya demi mempertahankan keberlanjutan bisnisnya. Hasil observasi atas variasi yang dialami harga saham perusahaan tersebut selama periode 2007 sampai 2016, yang dirangkum dalam Tabel 1, menunjukkan terjadi fluktuatif bahwa perusahaan relatif kurang mampu menciptakan kenaikan harga sahamnya secara berkesinambungan, sehingga 
pada tahun-tahun terjadi stagnasi ataupun penurunan atas harga saham perusahaan. Trend fluktuatif itu menunjukkan bahwa terdapat beberapa variabel yang harus diperhitungkan oleh pihak perusahaan dalam upayanya memperoleh kenaikan harga saham.Apabila mampu merespon perubahan-perubahan yang terjadi atas variabel-variabel tersebut, maka perusahaan lebih mungkin untuk mampu meningkatkan nilai perusahaannya melalui indikator meningkatnya harga sahamnya, dimana hal ini juga berimplikasi pada peningkatan kekayaan yang dinikmati para pemegang sahamnya.

Gambar 1.Trend Harga Saham PT. Bank Central Asia, Tbk.

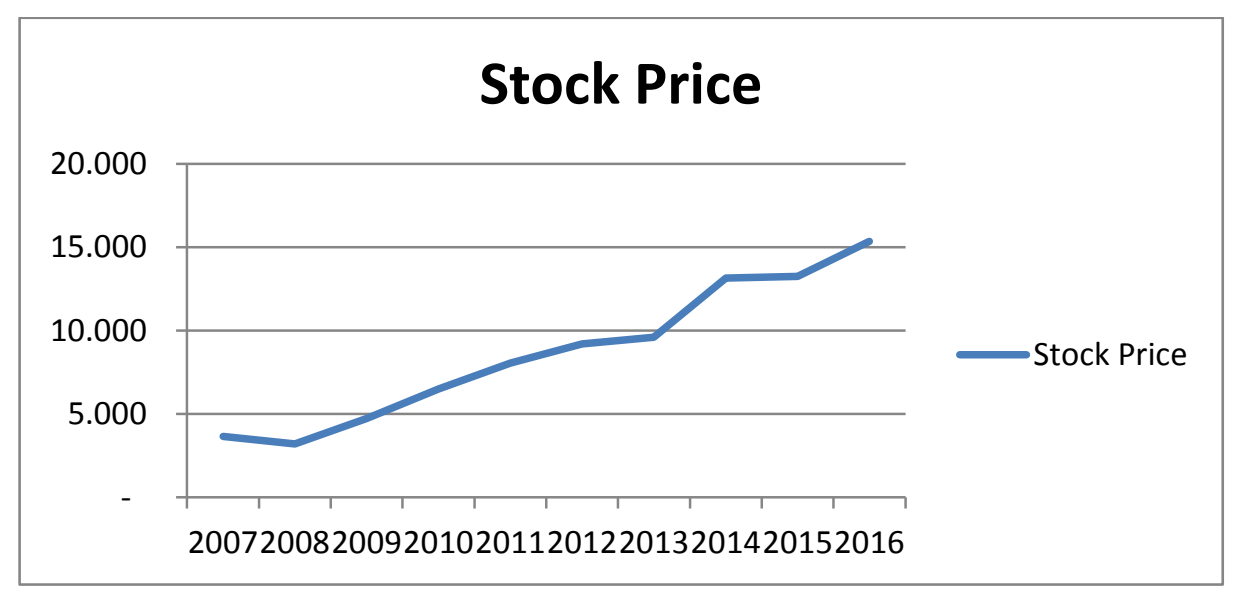

Sumber: www.bca.co.id (diolah), tahun 2018

Fitriyanto (2013) berargumen bahwa struktur modal merupakan salah satu variabel yang mempengaruhi nilai perusahaan.Pengkajian struktur modal lebih ditekankan untuk mencari komposisi yang paling optimal di antara elemen-elemen permodalan jangka panjang agar menghasilkan nilai perusahaan yang baik (Salempang dkk., 2016; Darminto, 2010). Struktur modal menggambarkan bentuk proporsi finansial perusahaan yang dimiliki perusahaan, yaitu proporsi antara modal asing perusahaan yang berasal dari pinjaman jangka panjang (long-term liabilities) dan modal sendiri miliknya (shareholders' equity).Keduanya menjadi sumber pembiayaan utama bagi perusahaan (Fahmi, 2014; Ismail, 2010).Daya hidup jangka panjang perusahaanseharusnya didukung oleh kombinasi optimal dari kedua tipe modal tersebut. Apabila perusahaan mampu mengelola dan merespon secara cepat dan tepat terkait sumber-sumber dana yang dimilikinya yang dipakai untuk memperkuat struktur modal, maka perusahaan mampu meminimalkan risiko bisnis yang ditanggungnya, namun berimplikasi kuat terhadap apa yang bisa terjadi pada arah kegiatan perusahaan di masa yang datang (Kusumaningrum\& Rahardjo, 2013; Gitman \& Zutter, 2012; Karadeniz et al., 2009).

Selain faktor internal seperti komposisi struktur modal, nilai perusahaan dipandang juga dipengaruhi oleh faktor-faktor eksternal seperti inflasi, suku bunga, dan nilai tukar (kurs).

Inflasi memberikan pengaruh atas nilai perusahaan dimana jika terjadi inflasi yang tinggi maka bisa mendorong kenaikan harga bahan baku ataupun biaya operasional yang ditanggung 
perusahaan, sehingga menggerus nilai keuntungan yang diperolehnya (Prasetyo, 2011; Suryantini \& Arsawan, 2014). Penurunan nilai laba yang diperoleh akibat dampak inflasi itu bisa memunculkan penilaian negatf dan menurunnya minat investor berinvestasi dalam perusahaan itu yang dinilai memiliki prospek yang kurang menguntungkan, dan akhirnya berakibat menurunnya harga saham atau nilai dari perusahaan tersebut (Dae\& Silvy, 2015; Chidothi\&Sheefeni, 2013; Mousa et al., 2012).

Faktor eksternal lain yang dianggap bisa mempengaruhi nilai perusahaan adalah tingkat suku bunga (interest rate). Pada kondisi terjadinya tingkat suku bunga yang tinggi dimana jika imbal hasil yang ditawarkan oleh perbankan dinilai jauh lebih tinggi yang bisa diperoleh melalui pasar modal, para investor lebih memutuskan untuk memindahkan dananya dari pasar modal dan menginvestasikannya pada produk-produk simpanan milik perbankan (Rismawati \& Dana, 2014; Hamrita \& Trifi, 2011). Kondisi ini menyebabkan terjadinya penurunan harga saham, dan selanjutnya berdampak menurunkan nilai perusahaan (Kusuma, 2016; Momani \& Alsharari, 2012; Oshaibat \& Majali, 2016).

Faktor eksternal ketiga yang dianggap mempengaruhi nilai perusahaan adalah nilai tukar atau kurs mata uang (exchange rate). Apabila terjadi apresiasi ataupun depresiasi nilai tukar mata uang nasional dinilai akan bisa mempengaruhi nilai suatu perusahaan (Prasetyo, 2011; Kewal, 2012). Sebagai misal, terjadi depresiasi nilai tukar nasional, sementara perusahaan yang bersangkutan bergantung pada bahan baku impor, maka akan terjadi kenaikan biaya produksi dan selanjutnya berdampak mengurangi keuntungan yang diperoleh. Berkurangnya nilai keuntungan yang dicapai akan memunculkan sentiment negatif dan membuat para investor enggan untuk berinvestasi pada perusahaan itu, dan pada akhirnya akan menurunkan nilai perusahaan di pasar (Gay Jr., 2016; AlAbdallah \& Aljarayesh, 2017; Ginting dkk., 2016)

Secara lebih mendalam, tujuan penelitian ini adalah untuk menganalisis bagaimana struktur modal serta faktor-faktor eksternal yang meliputi inflasi, suku bunga dan nilai tukar, memiliki pengaruh terhadap nilai perusahaan dari PT. Bank Central Asia, Tbk., baik secara parsial ataupun simultan.

\section{TINJAUAN PUSTAKA}

\section{Nilai Perusahaan}

Tujuan yang ingin dicapai oleh sebuah perusahaantidak hanya sekedar memaksimalkan laba yang bisa diperoleh, tetapi yang utama adalah bagaimana memaksimalkan nilai perusahaan. Nilai perusahaan merupakan indikator utama yang dipertimbangkan oleh investor dalam proses pengambilan keputusan berinvestasi dalam sebuah perusahaan (Fuad dkk., 2017; Gitman \& Zutter, 2012). Nilai perusahaan bagi perusahaan yang terdaftar di pasar modal dicerminkan oleh harga sahamnya, dimana semakin tinggi harga saham maka menunjukkan semakin tinggi nilai perusahaan yang bersangkutan (Husnan \& Pudjiastuti, 2012; Margaretha, 2013).Nilai perusahaan yang semakin tinggi juga bisa diartikan bahwa semakin tingginya tingkat kesejahteraan yang dinikmati oleh 
pemegang saham (stockholders' wealth) (Liembono, 2016). Dengan demikian, nilai perusahaan yang tinggi akan menciptakan dan kepercayaan tinggi dari pasar, tidak hanya berkaitan dengan kinerja perusahaan saat ini, tetapi juga sentimen positif mengenai prospek masa depan dari perusahaan yang bersangkutan (Halim, 2015; Fahmi, 2014).

Selain berdasarkan harga saham secara nominal per lembar, nilai perusahaan juga dapat diukur menggunakan sejumlah rasio penilaian.Salah satu rasio penilaian atas nilai perusahaan adalah Price to Book Value (PBV) yang merupakan perbandingan antara harga pasar per lembar saham (market price per share) terhadap nilai buku per lembar saham (book value per share).PBV menggambarkan seberapa besar pasar menghargai nilai buku dari saham perusahaan, dengan kriteria bahwa semakin besar nilai PBV maka menunjukkan semakin tinggi kepercayaan pasar atas perusahaan yang bersangkutan (Suryantini \& Arsawan, 2014; Brigham \& Houston, 2013).Dengan demikian, semakin besar nilai PBV menyatakan semakin tingginya tingkat kepercayaan pasar terhadap prospek pertumbuhan dari perusahaan, sehingga semakin memperkuat keyakinan para investor untuk menginvestasikan uangnya dalam perusahaan tersebut yang mana mendorong harga saham perusahaan, dan akhirnya menaikkan nilai perusahaan yang bersangkutan.

\section{Hubungan Struktur Modal dan Nilai Perusahaan}

Struktur modal merupakan faktor internal yang dinilai mempengaruhi nilai perusahaan.Struktur modal (capital structure) menggambarkan proporsi pembiayaan utama yang dimiliki perusahaan, yaitu perbandingan antara modal asing perusahaan yang berasal dari kewajiban jangka panjang (long-term liabilities) dan modal sendiri (shareholders' equity) (Halim, 2015; Fahmi, 2014; Ismail, 2010).Pengkajian pada struktur modal lebih ditekankan untuk mencari komposisi yang optimal antara elemen-elemen modal asing jangka panjang dan modal sendiri agar menghasilkan nilai perusahaan yang baik (Salempang dkk., 2016; Darminto, 2010). Apabila perusahaan mampu mengelola dan merespon secara cepat dan tepat terkait sumber-sumber dana yang dimilikinya yang dipakai untuk memperkuat struktur modal, maka perusahaan dinilai akan mampu meminimalkan risiko bisnis yang ditanggungnya, sehingga memperkuat sentimen positif dari pasar atas perusahaan dan berimplikasi pada peningkatan nilai perusahaannya (Kusumaningrum \& Rahardjo, 2013; Gitman \& Zutter, 2012; Karadeniz et al., 2009). Dalam penelitian ini, struktur modal diukur menggunakan rasio debt to equity (DER), yang menyatakan perbandingan antara total utang atau kewajiban yang dimiliki perusahaan terhadap modal sendiri; dengan kriteria bahwa semakin kecil nilai rasio ini maka proporsi struktur modal dinilai semakin baik karena besaran modal sendiri lebih besar dari total kewajibannya, atau bahwa perusahaan dinilai semakin memiliki kemandirian keuangan dan berarti semakin tinggi nilai perusahaannya (Fahmi, 2014; Brigham \& Houston, 2013)

Hasil-hasil penelitian yang diperoleh Suteja dan Manihuruk (2009), Pratama \& Wirawati (2016), Salempang dkk.(2016), serta Sartini dan Purbawangsa (2015), menemukan bahwa struktur modal berpengaruh positif ataupun signifikan terhadap nilai perusahaan. Hasil ini sesuai dengan alur 
pemikiran bahwa apabila perusahaan mampu mengelola komposisi stuktur modalnya dengan baik, maka akan menciptakan keyakinan pasar atas prospek pertumbuhannya di masa datang, dan selanjutnya akan mempertinggi nilai perusahaan.Berdasarkan alur pemikiran yang telah diuraikan, maka dimunculkan hipotesis pertama yaitu:

H1: Struktur modal memiliki pengaruh yang positif dan signifikan terhadap nilai perusahaan.

\section{Hubungan Inflasi dan Nilai Perusahaan}

Faktor eksternal pertama yang dianalisis dalam penelitian adalah inflasi (inflation rate).Inflasi merupakan kondisi kenaikan harga dari barang-barang secara umum dan terus menerus, yang diakibatkan oleh terganggunya aspek keseimbangan antara arus barang dan arus uang (Mishkin, 2008; Gilarso, 2004; Khalwaty, 2000).Saat terjadi inflasi yang tinggi maka bisa mendorong kenaikan harga bahan baku ataupun biaya operasional yang ditanggung, yang selanjutnya menggerus nilai keuntungan yang diperoleh perusahaan (Zakaria, 2009; Prasetyo, 2011; Suryantini \& Arsawan, 2014). Penurunan capaian nilai laba akibat dampak inflasi bisa memunculkan penilaian negatif oleh pasar bahwa perusahaan yang bersangkutan tidak memiliki kinerja keuangan yang baik, berikutnya menurunkan minat investor berinvestasi, dan akhirnya berakibat pada menurunnya nilai perusahaan tersebut (Dae \& Silvy, 2015; Chidothi \& Sheefeni, 2013; Mousa et al., 2012).Dalam penelitian ini, tingkat inflasi menggunakan data Indeks Harga Konsumen (IHK atau consumer price index) dari laporan inflasi akhir tahun yang dipublikasikan oleh Bank Indonesia.IHK merupakan ukuran harga rata-rata dari barang dan jasa yang dikonsumsi oleh rumah tangga (household), dan merupakan indikator yang digunakan pemerintah untuk mengukur inflasi di Indonesia.

Temuan-temuan studi milik Wijaya dan Wibawa (2010), Suryantini \& Arsawan (2014) serta Al-Abdallah dan Aljarayesh (2017), dalam studi mereka menemukan adanya hubungan positif antara inflasi dan nilai perusahaan. Berdasarkan pemikiran bahwa apabila terjadi kenaikan nilai inflasi akan menurunkan nilai perusahaan dari PT. Bank Central Asia, Tbk.,maka dimunculkan hipotesis kedua yaitu:

H2: Inflasi memiliki pengaruh yang negatif dan signifikan terhadap nilai perusahaan.

\section{Hubungan Suku Bunga dan Nilai Perusahaan}

Faktor eksternal kedua yang dianalisis dalam penelitian ini adalah tingkat suku bunga (interest rate). Suku bunga merupakan biaya pinjaman atau harga yang harus dibayarkan atas dana pinjaman tersebut, atau merupakan harga atas sumber daya yang digunakan oleh penerima pinjaman (debitur) kepada pihak pemberi pinjaman (kreditur) (Liembono, 2016; Noerirawan \& Muid, 2012; Zakaria, 2009). Secara khusus, proses transaksi yang terjadi di dalam sektor perbankan tidak bisa lepas dari unsur suku bunga ini, baik terkait produk-produk simpanan maupun pinjaman yang menghasilkan pendapatan berbasis bunga (interest-based income) bagi bank (Mishkin, 2008; Ismail, 2010).Dalam penelitian ini, suku bunga direpresentasi menggunakan nilai BI Rate atau tingkat suku bunga dari 
laporan akhir tahun yang dipublikasikan oleh Bank Indonesia.BI Rate merupakan tingkat suku bunga yang ditetapkan Bank Indonesia secara triwulanan sebagai signaling bagi suku bunga-suku bunga lainnya (Mishkin, 2008; Prasetyo, 2011; Khalwaty, 2000).Dalam arti, semua besaran moneter dan perbankan mengacu pada $B I$ Rate ini termasuk di dalamnya tingkat suku bunga perbankan umum.BI Rate merupakan suku bunga acuan atau dasar bagi bank-bank di Indonesia dalam menetapkan tingkat bunga produk-produk simpanan maupun pinjaman yang akan mereka tawarkan kepada para calon nasabah mereka.

Temuan studi milik Kusuma (2016) menemukan bahwa tingkat bunga memiliki hubungan yang positif dengan nilai perusahaan.Berdasarkan pemikiran bahwa apabila terjadi kenaikan tingkat suku bunga akan menurunkan nilai perusahaan dari PT. Bank Central Asia, Tbk., maka dimunculkan hipotesis ketiga yaitu:

H3: Suku bunga memiliki pengaruh yang negatif dan signifikan terhadap nilai perusahaan.

\section{Hubungan Nilai Tukar (Kurs) dan Nilai Perusahaan}

Nilai tukar atau kurs mata uang (exchange rate) adalah faktor eksternal ketiga yang dianalisis dalam penelitian ini.Nilai tukar (kurs) adalah harga suatu mata uang terhadap mata uang yang lain, atau merupakan harga satu unit mata uang asing dalam mata uang domestik ataupun harga satu unit mata uang domestik dalam mata uang asing (Levi, 2009; Hady, 2016). Derajat stabilitas atas nilai tukar mata uang suatu negara dinilai menunjukkan situasi perekonomian Negara yang bersangkutan, dan bisa mempengaruhi keyakinan para investor terutama yang berasal dari luar negeri untuk menanamkan modalnya di negara tersebut. Menguatnya nilai tukar Rupiah (atau, IDR) terhadap mata uang asing akan memberikan sinyal positif bagi perkembangan perekonomian Indonesia; aatau sebaliknya, melemahnya nilai IDR bisa memberi sinyal memburuknya perekonomian nasional (Tandelilin, 2010; Mishkin, 2008). Lebih jauh, terjadinya kondisi apresiasi ataupun depresiasi nilai tukar mata uang nasional dinilai akan bisa mempengaruhi nilai suatu perusahaan; dimana investor menghubungkan perkiraan nilai imbalan (rate of return) atau tingkat pertambahan nilai investasi miliknya yang tertanam di pasar modal dengan perkiraan perubahan nilai kurs (Prasetyo, 2011; Kewal, 2012). Dalam penelitian ini, nilai tukar diukur menggunakan nilai Kurs Tengah antara mata uang nasional (IDR) terhadap mata uang dollar (USD) berdasarkan laporan akhir tahun yang dipublikasikan secara rutin oleh Bank Indonesia.Nilai kurs tengah ini bisa digunakan sebagai acuan nilai konversi mata uang asing di dalam laporan keuangan oleh perusahaan-perusahaan yang beroperasi di wilayah Indonesia.

Hasil penelitian terdahulu milik Wangbangpo dan Sharma (2002), Kandir (2008), Ginting dkk.(2016) serta Gay Jr. (2016), menemukan bahwa nilai tukar memiliki hubungan yang positif dengan nilai perusahaan.Berdasarkan pemikiran bahwa apabila terjadi kenaikan nilai tukar akan menurunkan nilai perusahaan dari PT. Bank Central Asia, Tbk., maka dimunculkan hipotesis keempat yaitu: 
H4: Nilai tukar (kurs) memiliki pengaruh yang negatif dan signifikan terhadap nilai perusahaan.

\section{Hubungan Simultan}

Setelah menguraikan dasar hipotesis dari hubungan parsial, penelitian ini juga bertujuan menganalisis bagaimana pengaruh simultan antara struktur modal dan faktor-faktor eksternal (inflasi, suku bunga dan nilai tukar) terhadap nilai perusahaan.Juga, penelitian ini ingin mengidentifikasi besaran kontribusi dari struktur modal dan faktor-faktor eksternal tersebut dalam menjelaskan variasi atau perubahan yang terjadi atas nilai perusahaan dari PT. Bank Central Asia, Tbk. Upaya ini dipandang perlu dilakukan karena pihak perusahaan membutuhkan acuan ataupun bahan pertimbangan agar mampu mengelola struktur modal yang dimilikinya serta merespon perubahan-perubahan yang terjadi atas faktor-faktor eksternal demi menciptakan nilai perusahaan yang terus meningkat bagi para pemiliknya.Berdasarkan pemikiran tersebut, maka dimunculkan hipotesis kelima yaitu:

H5: Struktur modal dan faktor-faktor eksternal (inflasi, suku bunga dan nilai tukar) memiliki pengaruh simultan yang signifikan terhadap nilai perusahaan.

\section{METODE PENELITIAN}

Data sekunder berupa laporan keuangan perusahaan yang meliputi neraca dan laporan laba rugi yang diperoleh melalui www.idx.co.id dan www.bca.co.id; sementara data mengenai inflasi, suku bunga, dam milai tukar, diperoleh melalui www.bi.go.id.Periode penelitian adalah tahun 2007 sampai 2016. Data sekunder dikumpulkan melalui metode dokumentasi, yaitu prosesmengumpulkan semua laporan keuangan yang telah dipublikasikan milik obyek penelitian selama periode penelitian, memilah data yang dibutuhkan bagi proses analisis, dan merangkum data yang telah dipilih tersebut, untuk kemudian dilanjutkan pada proses analisis data (Sugiyono, 2015; Situmorang \& Muslich, 2014).

Metode analisis data menggunakan regresi linier berganda, yang bertujuan untuk mengidentifikasi arah dan besaran dari pengaruh atau hubungan antara dua atau lebih variabel independen terhadap variabel dependen (Sekaran \& Bougie, 2013; Sugiyono, 2015).Selanjutnya, dilakukan pengujian atas hipotesis-hipotesis yang diajukan dalam penelitian ini, yang dibedakan antara pengujian secara parsial (uji $t$ ) dan pengujian secara simultan (uji $F$ ). Uji $t$ ( $t$-test) digunakan untuk mengidentifikasi bagaimana pengaruh dari variabel-variabel independen secara parsial atau individu terhadap variabel dependen; dengan kriteria jika diperoleh nilai Sig. $t<\alpha(0,05)$ maka dinyatakan variabel independen memiliki pengaruh parsial yang signifikan terhadap variabel dependen, atau sebaliknya jika diperoleh nilai Sig. $t>\alpha(0,05)$ maka dinyatakan variabel independen memiliki pengaruh parsial yang tidak signifikan terhadap variabel dependen (Sekaran \& Bougie, 2013; Sugiyono, 2015).

Uji $F$ (F-test) digunakan untuk mengidentifikasi bagaimana pengaruh dari variabel-variabel independen secara simultan atau serempak terhadap variabel dependen; dengan kriteria jika diperoleh nilai Sig. $F<\alpha(0,05)$ maka dinyatakan variabel-variabel independen memiliki pengaruh simultan yang 
signifikan terhadap variabel dependen, atau sebaliknya jika diperoleh nilai Sig. $F>\alpha(0,05)$ maka dinyatakan variabel-variabel independen memiliki pengaruh simultan yang tidak signifikan terhadap variabel dependen (Sekaran \& Bougie, 2013; Sugiyono, 2015).

\section{HASIL DAN PEMBAHASAN}

\section{Analisis Regresi}

Analisis regresi berganda digunakan untuk mengetahui bagaimana pengaruh dari dua atau lebih variabel independen terhadap satu variabel dependen.Dalam penelitian ini terdapat empat variabel independen, yaitu struktur modal, inflasi, suku bunga dan nilai tukar; sementara variabel dependen adalah nilai perusahaan.Hasil analisis statistik ditunjukkan dalam Tabel 1.

Tabel 1. Hasil Analisis Statistik

\begin{tabular}{|c|c|c|c|}
\hline Variabel & B & $\mathrm{t}$ & Sig. t \\
\hline Konstanta & 15.536 & 2.064 & .094 \\
\hline $\mathrm{X} 1$ & -.539 & -.768 & .477 \\
\hline $\mathrm{X} 2$ & -.050 & -.319 & .763 \\
\hline $\mathrm{X} 3$ & .314 & .354 & .738 \\
\hline $\mathrm{X} 4$ & -.001 & -1.197 & .285 \\
\hline R. Square & $=.748$ & & \\
\hline $\mathrm{F}$ & $=3.714$ & & \\
\hline Sig. F & $=.091$ & & \\
\hline
\end{tabular}

Sumber: Data sekunder (diolah), Tahun 2018

Berdasarkan Tabel 1 maka dapat diformulasikan model regresi untuk penelitian ini yaitu:

$$
\mathrm{Y}=15,536-0,539 \mathrm{X} 1-0,050 \mathrm{X} 2+0,314 \mathrm{X} 3-0,001 \mathrm{X} 4
$$

Hasil dalam Tabel 1 tersebut dapat diinterpretasikan bahwa struktur modal (X1),inflasi (X2) dan nilai tukar/kurs (X4) memiliki pengaruh dengan arah negatif terhadap nilai perusahaan. Yang berarti, jika salah satu dari ketiga variabel independen ini mengalami kenaikan (penurunan), dengan asumsi jika variabel-variabel independen lainnya yang dianalisis dalam model penelitian bersifat tetap atau tidak mengalami perubahan nilai, maka nilai perusahaan juga mengalami penurunan (peningkatan).

Hasil dalam Tabel 1 juga menunjukkan bahwa suku bunga (X3) memiliki pengaruh dengan arah positif terhadap nilai perusahaan.Hal ini berarti bahwa apabila variabel independen ini mengalami kenaikan (penurunan), dengan asumsi jika variabel-variabel independen lainnya bersifat tetap atau tidak mengalami perubahan nilai, maka nilai perusahaan juga mengalami peningkatan (penurunan).

Lebih jauh, hasil analisis regresi pada Tabel 1 menyatakan bahwa variabel struktur modal (X1) memiliki pengaruh paling besar atau dominan terhadap nilai perusahaan, dibandingkan ketiga variabel independen yang lain.

\section{Uji Hipotesis}

Dalam penelitian ini terdapat lima hipotesis yang di uji, yang meliputi empat hipotesis diuji 
secara parsial dan satu hipotesis diuji secara simultan.Hasil masing-masing uji hipotesis diuraikan berikut ini.

1. Uji Parsial (uji $t)$.

Hasil uji hipotesis secara parsial antara masing-masing variabel independenterhadap variabel dependen, ditunjukkan dalam Tabel 1. Berdasarkan tabel tersebut terlihat bahwa nilai Sig. $t$ dari variabel-variabel independen $(\mathrm{X} 1=0,477 ; \mathrm{X} 2=0,763 ; \mathrm{X} 3=0,738 ; \mathrm{X} 4=0,285)$ adalah lebih besar dari $\alpha(0,05)$. Berdasarkan hasil tersebut, diinterpretasikan bahwavariabel-variabel independen, yaitu struktur modal (X1), inflasi (X2), suku bunga (X2) dan nilai tukar (X3), memiliki pengaruh parsial yang tidak signifikan terhadap variabel dependen (Y) yaitu nilai perusahaan. Dengan demikian, hipotesis 1 sampai 4 dinyatakan ditolak atau tidak terbukti kebenarannya.

2. Uji Simultan (uji $F$ ).

Hasil uji hipotesis secara simultan antara semua variabel independen terhadap variabel dependen, ditunjukkan dalam Tabel 1. Berdasarkan tabel tersebut terlihat bahwa nilai Sig. F sebesar 0,091 adalah lebih besar dari $\alpha(0,05)$. Berdasarkan hasil tersebut, diinterpretasikan bahwa semua variabel independen memiliki pengaruh simultan yang tidak signifikan terhadap variabel dependen.Dengan demikian, hipotesis 5 dinyatakan ditolak atau tidak terbukti kebenarannya.

\section{Koefisien Determinasi}

Analisis koefisien determinasi bertujuan mengidentifikasi besaran kontribusi dari variabelvariabel independen terhadap variabel dependen.Hasil analisis koefisien determinasi ditunjukkan dalam Tabel 1.Berdasarkan tabel tersebut terlihat bahwa nilai $R$ Square sebesar 0,748. Berdasarkan nilai tersebut, diinterpretasikan bahwa variabel-variabel independen yang dimasukkan dalam model penelitian ini memiliki kontribusi sebesar 74,8\% untuk menjelaskan perubahan-perubahan yang terjadi pada variabel dependen. Sisanya sebesar 25,2\% menyatakan bahwa masih terdapat variabel-variabel lain yang dinilai turut mempengaruhi variasi dari vaiabel dependen namun tidak tercakup di dalam model penelitian ini.

\section{Pembahasan}

Berdasarkan hasil analisis diperoleh bahwa struktur modal memiliki pengaruh negatif dan tidak signifikan terhadap nilai perusahaan.Lebih jauh, hasil regresi menyatakan bahwa variabel ini memiliki pengaruh dominan terhadap nilai perusahaan.Struktur modal merupakan kombinasi antara modal sendiri dan modal asing jangka panjang, atau merupakan perbandingan proporsi antara modal sendiri dengan bentuk-bentuk kewajiban jangka panjang (Gumanti, 2017; Halim, 2015; Setiani, 2013).Hasil ini sesuai dengan yang diperoleh Kusumaningrum dan Rahardjo (2013) Kusuma (2016), serta Noerirawan \& Muid (2012) dalam studi mereka, sedikit berbeda dengan hasil studi Dae dan Silvy (2015), bahwa struktur modal berpengaruh negatif namun signifikan terhadap nilai 
perusahaan.Namun hasil ini berbeda dengan hasil studi Suteja dan Manihuruk (2009), Pratama \& Wirawati (2016), Salempang dkk.(2016),serta Sartini dan Purbawangsa (2015); yang menemukan bahwa struktur modal berpengaruh positif ataupun signifikan terhadap nilai perusahaan.Berdasarkan hasil ini, PT. Bank Central Asia, Tbk. dipandang perlu memberikan perhatian lebih terkait penentuan komposisi struktur modal yang optimal, yaitu perbandingan antara modal sendiri dan modal asing yang dimilikinya (Fahmi, 2014; Gitman \& Zutter, 2012). Hal ini karena struktur modal merupakan faktor yang berpengaruh paling besar terhadap pencapaian nilai perusahaan yang tinggi, yang berarti apabila perusahaan mampu melakukan upaya optimalisasi atas komposisi struktur modal, maka akan memberikan manfaat sangat besar bagi keberhasilan meningkatkan nilai perusahaannya. Porsi utang yang besar akan memberikan beban bunga yang besar bagi perusahaan dan mengurangi besarnya keuntungan yang diperolehnya, dan memberi imej negatif bagi investor bahwa perusahaan tidak bisa memperoleh laba yang besar dan akhirnya menurunkan nilai perusahaan. Hasil analisis yang menyatakan bahwa struktur modal memiliki pengaruh negatif terhadap nilai perusahaan diduga adalah karena sektor perbankan memiliki struktur modal yang didominasi oleh modal asing berupa bentukbentuk simpanan jangka pendek maupun jangka panjang milik para nasabah (Sartini \&Purbawangsa, 2015; Dae \& Silvy, 2015). Terkait pemikiran ini, maka dibutuhkan upaya produktif dalam mengelola dana asing tersebut melalui produk-produk pinjaman/kredit sehingga memberikan keuntungan maksimal bagi perusahaan, sehingga probabilitas default risk bisa diminimalkan ataupun dihindari.

Inflasi merupakan kondisi kenaikan harga dari barang-barang secara umum dan terus menerus, yang diakibatkan oleh terganggunya aspek keseimbangan antara arus barang dan arus uang; apabila kenaikan harga hanya dialami oleh satu atau dua barang saja, maka kondisi itu tidak bisa disebut inflasi (Mishkin, 2008; Gilarso, 2004; Khalwaty, 2000).Hasil analisis kedua dalam penelitian ini menunjukkan bahwa variabel eksternal berupa inflasi memiliki pengaruh negatif namun tidak signifikan terhadap nilai perusahaan.Hasil ini sejalan dengan temuan Kewal (2012), Almilia dan Silvy(2003),Kusuma (2016), serta Ginting dkk.(2016) yang juga menemukan bahwa pengaruh inflasi bersifat negatif dan tidak signifikan terhadap nilai perusahaan. Tetapi hasil penelitian ini berbeda dengan temuan dari Wijaya dan Wibawa (2010),Suryantini \& Arsawan (2014) serta Al-Abdallah dan Aljarayesh (2017), yang menemukan adanya hubungan signifikan ataupun positif antara inflasi dan nilai perusahaan. Hasil penelitian ini menyatakan bahwa apabila terjadi kenaikan nilai inflasi maka akan menurunkan nilai perusahaan dari PT. Bank Central Asia, Tbk. Hal ini bisa dikaitkan dengan pemikiran bahwa apabila inflasi mengalami peningkatan, yang berarti terjadi kenaikan harga barangbarang secara umum, maka investor lebih memilih mengkonversi investasi surat berharganya menjadi uang tunai yang kemudian dialokasikan untuk memenuhi kebutuhan hidupnya sehari-hari.Ataupun, kondisi inflasi umumnya diikuti kebijakan intervensi pemerintah dengan menaikkan suku bunga, yang bisa menarik para investor untuk memindahkan investasinya dari pasar modal kepada perbankan. Penarikan dana yang besar oleh para investor dari pasar modal berarti adanya aksi jual sekuritas dalam 
jumlah besar, yang selanjutnya menyebabkan turunnya harga saham perusahaan dan berarti menurunnya nilai perusahaan(Chidothi\&Sheefeni, 2013; Mousa et al., 2012).

Terkait faktor eksternal berupa suku bunga (interest rate), hasil penelitian ini menunjukkan adanya pengaruh yang positif dan tidak signifikan dengan nilai perusahaan. Tingkat suku bunga adalah merupakan biaya pinjaman atau harga yang harus dibayarkan atas dana pinjaman tersebut, atau merupakan harga atas sumber daya yang digunakan oleh penerima pinjaman (debitur) kepada pihak pemberi pinjaman (kreditur) (Liembono, 2016; Noerirawan \& Muid, 2012; Zakaria, 2009). Proses transaksi yang terjadi di dalam sector perbankan tidak bisa lepas dari unsur suku bunga ini. Hasil yang diperoleh dalam penelitian ini sama dengan temua studi milik Kusuma (2016), bahwa tingkat bunga memiliki hubungan yang positif dengan nilai perusahaan. Namun hasil studi ini tidak sejalan dengan pendapat Tandelilin (2010) bahwa tingkat bunga memiliki hubungan yang negatif terhadap nilai perusahaan yang direpresentasi oleh harga saham. Hasil penelitian ini juga berbeda dengan temuan studi milik Kewal (2012), Momami dan Alsharari (2012), Oshaibat \& Majali (2016), maupun Rismawati dan Dana (2016), yang menemukan hubungan yang negatif ataupun signifikan antara tingkat suku bunga dan nilai perusahaan. Hasil penelitian ini bisa diinterpretasikan bahwa apabila tingkat suku bunga yang direpresentasi oleh SBI mengalami kenaikan, berarti suku bunga yang ditawarkan PT. Bank Central Asia, Tbk. atas produk-produk simpanannya menjadi lebih tinggi dan hal ini dinilai akan menarik nasabah lama maupuu nasabah baru untuk menambah jumlah tabungan atau depositonya, serta juga menarik para investor untuk mengalihkan dana investasinya dari surat berharga ke dalam perbankan; dengan catatan bahwa imbal hasil yang diterima para investor itu dari instrument simpanan perbankan adalah lebih tinggi yang bisa diperoleh melalui instrument sekuritas pasar modal (Rismawati \& Dana, 2014; Hamrita \& Trifi, 2011). Sifat hubungan yang positif ini juga bisa menyatakan adanya keyakinan yang tinggi dari para investor bahwa bank yang bersangkutan mampu mengelola modal sendiri maupun modal asing dari produk-produk simpanan secara produktif dengan mendistribusikannya pada produk-produk pinjaman/kredit yang tentu juga mengalami kenaikan nilai bunganya, sehingga bisa menghasilkan benefit atau pendapatan yang besar bagi bank tersebut, dan selanjutnya bisa mempertinggi kemakmuran yang dirasakan para investornya. Kondisi ini tentu dengan asumsi bahwa PT. Bank Central Asia, Tbk. harus mampu meluncurkan strategi-strategi pemasaran yang tepat dalam 'merayu' para nasabah lama ataupun calon nasabah untuk bersedia memanfaatkan produk-produk pinjaman yang ditawarkan.

Hasil penelitian berikutnya terkait faktor eksternal ketiga yaitu nilai tukar atau kurs (exchange rate). Nilai tukar atau disebut juga kurs (exchange rate) merupakan harga suatu mata uang terhadap mata uang yang lain, ataupun harga satu unit mata uang asing dalam mata uang domestik atau harga satu unit mata uang domestik dalam mata uang asing (Levi, 2009; Hady, 2016). Stabilitas yang terjadi atas nilai tukar mata uang suatu negara akan mempengaruhi keyakinan investor untuk menanamkan modalnya di negara tersebut. Menguatnya nilai tukar Rupiah (atau, IDR) terhadap mata uang asing 
akan memberikan sinyal positif bagi perkembangan perekonomian Indonesia; aatau sebaliknya, melemahnya nilai IDR bisa memberi sinyal memburuknya perekonomian nasional (Tandelilin, 2010; Mishkin, 2008).Hasil penelitian ini menyatakan bahwa terdapat pengaruh negatif dan tidak signifikan antara nilai tukar dan nilai perusahaan, yang mana sejalan dengan temuan studi milik Suteja dan Manihuruk (2009), Kusuma (2016), serta Al-Abdallah dan Aljarayesh (2017).Namun demikian, hasil penelitian ini berbeda dengan yang ditemukan oleh Wangbangpo dan Sharma (2002), Kandir (2008), Ginting dkk. (2016) serta Gay Jr. (2016), bahwa nilai tukar memiliki hubungan yang positif dengan nilai perusahaan yang diukur menggunakan harga ataupun return saham. Hasil penelitian ini menunjukkan bahwa nilai tukar memberikan pengaruh negatif tidak signifikan terhadap nilai perusahaan; dalam arti, apabila terjadi kenaikan nilai inflasi ataupun kenaikan nilai tukar mata IDR terhadap USD (atau, kurs terapresiasi), maka akan menurunkan nilai perusahaan dari PT. Bank Central Asia, Tbk. Hal ini bisa dikaitkan dengan pemikiran bahwa apabila nilai tukar mata uang mengalami apresiasi, maka investor lebih cenderung memborong dollar karena murah dan memindahkan nilai investasinya di pasar modal ke dalam instrumen pasar valuta asing (Suteja \& Manihuruk, 2009; Kusuma, 2016; Al-Abdallah dan Aljarayesh, 2017). Kondisi-kondisi itu bisa menyebabkan meningkatnya aksi jual atas instrumen sekuritas milik PT. Bank Central Asia, Tbk.dan pada berikutnya akan menurunkan harga saham bank tersebut, yang berarti menurunkan nilai perusahaannya.

Hasil analisis koefisien determinasi menunjukkan adanya kontribusi yang relatif besar dari variabel-variabel yang dianalisis dalam penelitian ini, yaitu struktur modal dan faktor-faktor eksternal (inflasi, suku bunga, dan nilai tukar), dalam menjelaskan variasi perubahan yang terjadi pada nilai perusahaan.PT. Bank Central Asia, Tbk. sebaiknya memiliki tim khusus dengan sistem pendukung yang mumpuni sehingga mampu bertugas secara intens memantau dan menganalisis perubahanperubahan yang terjadi atas tingkat inflasi, suku bunga, dan nilai tukar (kurs) nasional. Walau pengaruh dari faktor-faktor eksternal tersebut diidentifikasi bersifat tidak signifikan, baik secara parsial maupun simultan, namun tetap memberi pengaruh atas nilai perusahaan. Seberapa cepat dan cermat perusahaan dalam merespon perubahan dari factor-faktor eksternal tersebut maka akanmenpengaruhi capaian nilai perusahaannya yang diwakili oleh trend harga sahamnya (Mousa et al., 2012; Kusumaningrum \& Rahardjo, 2013; Husnan \& Pudjiastuti, 2012; Gay Jr., 2016).

Terakhir, hasil-hasil penelitian dapat menjadi referensi bagi pihak-pihak yang berkepentingan maupun para peneliti berikutnya untuk mengembangkan maupun memperdalam pemahaman mengenai bagaimana pengaruh struktur modal serta faktor-faktor eksternal terhadap nilai perusahaan. Para peneliti berikutnya dapat melakukan penelitian dengan memperbanyak faktor internal maupun eksternal yang diduga mempengaruhi nilai perusahaan, menambah jumlah perusahaan yang digunakan sebagai obyek penelitian baik dalam sektor industri yang sama maupun yang berbeda, ataupun 
menambah periode waktu penelitian, sehingga diperoleh wawasan yang lebih kaya dan mendalam terkait topik penelitian ini.

\section{KESIMPULAN DAN SARAN}

Berdasarkan hasil-hasil penelitian dan pembahasan yang telah diuraikan, bisa dinyatakan beberapa kesimpulan.Pertama, hasil analisis regresi menyimpulkan bahwa struktur modal (DER), inflasi dan nilai tukar (kurs) memiliki pengaruh bersifat negatif terhadap nilai perusahaan; sementara suku bunga berpengaruh positif terhadap nilai perusahaan dari PT. Bank Central Asia, Tbk. Lebih jauh, struktur modal memiliki pengaruh dominan terhadap nilai perusahaan.Kedua, hasil uji $t$ menunjukkan bahwa masing-masing variabel independen, yaitu struktur modal serta faktor-faktor eksternal (inflasi, suku bunga, dan kurs),memiliki pengaruh parsial yang tidak signifikan terhadap nilai perusahaan PT. Bank Central Asia, Tbk. Ketiga, hasil uji $F$ juga menyatakan bahwa semua variabel independen, yaitu struktur modal serta faktor-faktor eksternal (inflasi, suku bunga, dan kurs),memiliki pengaruh simultan yang tidak signifikan terhadap nilai perusahaan PT. Bank Central Asia, Tbk. Keempat, hasil koefisien determinasi menunjukkan bahwa struktur modal (DER), inflasi, suku bunga dan nilai tukar (kurs), memberikan kontribusi relatif besar dalam menjelaskan variasi yang terjadi pada nilai perusahaan PT. Bank Central Asia, Tbk.; walau demikian, masih terdapat variabel-variabel lain yang dipandang turut mempengaruhi nilai perusahaan namun tidak termasuk dalam model penelitian ini.

Berlandaskan kesimpulan-kesimpulan tersebut, maka disarankan agar PT. Bank Central Asia, Tbk. perlu memberikan perhatian lebih terkait penentuan komposisi struktur modal yang optimal, serta upaya produktif dalam mengelola struktur pendanaan sehingga memberikan keuntungan maksimal sekaligus meminimalkan default riskbagi perusahaan. Perusahaan juga perlu memantau secara intens sehingga dapat merespon perubahan dari faktor-faktor eksternal secara cepat dan cermat yang mana akan mempengaruhi capaian nilai perusahaannya. Selanjutnya, hasil-hasil penelitian ini dapat menjadi referensi bagi pihak-pihak yang berkepentingan maupun para peneliti berikutnya untuk mengembangkan maupun memperdalam pemahaman mengenai bagaimana pengaruh struktur modal serta faktor-faktor eksternal terhadap nilai perusahaan.

\section{REFERENSI}

Al-Abdallah, S.Y. dan Aljarayesh, N.I. 2017. Influence of Interest Rate, Exchange rate and Inflation on Common Stock Returns of Amman Stock Exchange, Jordan. International Journal of Economics, Commerce and Management.Vol. 5, No. 10, Hal.589-601.

Almilia, L.S. dan Silvy, M. 2003. Analisis Faktor-Faktor yang Mempengaruhi Status Perusahaan Pasca IPO dengan Menggunakan Tehnik Analisis Multinomal Logit. Jurnal Ekonomi dan Bisnis Indonesia. Vol.18, No. 4, Hal. 1-33.

Brigham, E.F. dan Houston, J.F. 2013. Fundamentals of Financial Management.14 ${ }^{\text {th }}$ Edition. Boston, USA: Cengage Learning. 
Chidothi, D. dan Sheefeni, P. S. 2013.The Relationship between Inflation and Stock Prices in Zambia.Asian Journal of Business and Management. Vol. 1, No.4, Hal.185-192.

Dae, C.N. dan Silvy, M. 2015. Pengaruh Faktor Internal dan Eksternal terhadap Nilai Perusahaan pada Perusahaan Manufaktur yang Terdaftar di Bursa Efek Indonesia (BEI). Artikel Ilmiah. Surabaya: Sekolah Tinggi Ilmu Ekonomi Perbanas.

Darminto. 2010. Pengaruh Faktor Eksternal dan Berbagai Keputusan Keuangan terhadap Nilai Perusahaan. Jurnal Aplikasi Manajemen. Vol.8, No.1, Hal. 138-150.

Fahmi,I.2014.Analisis Kinerja Keuangan.Bandung:Alfabeta.

Fitriyanto. 2013.Faktor-Faktor yang Mempengaruhi Struktur Modal dan Dampaknya terhadap Nilai Perusahaan. Skripsi. Fakultas Ekonomi. Universitas Negeri Semarang. Semarang.

Fuad, M., Nurbaya, S. dan Amirullah. 2017. Pengantar Bisnis. Yogyakarta: Indomedia Pustaka.

Gay Jr., R.D. 2016. Effect of Macroeconomic Variables on Stock Market Returns for Four Emerging Economies: Brazil, Russia, India, and China. International Business \& Economics Research Journal.Vol. 15, No. 3, Hal.119-125.

Gilarso, T. 2004. Pengantar Ilmu Ekonomi Makro. Yogyakarta: Kanisius.

Ginting, M.R.M., Topowijono dan Sulasmiyati, S. 2016. Pengaruh Tingkat Suku Bunga, Nilai Tukar dan Inflasi terhadap Harga Saham (Studi pada Sub-Sektor Perbankan di Bursa Efek Indonesia Periode 2011-2015). Jurnal Administrasi Bisnis (JAB). Vol. 35, No. 2, Hal.77-85.

Gitman, L.J. dan Zutter, C.J. 2012. Principles of Managerial Finance. $13^{\text {th }}$ Edition. Edinburgh Pearson.

Gumanti, T.A. 2017. Keuangan Korporat: Tinjauan Teori dan Bukti Empiris. Jakarta: Mitra Wacana Media.

Hady, H. 2016. Manajemen Keuangan Internasional. Edisi 4.Jakarta: Mitra Wacana Media.

Halim, A. 2015. Manajemen Keuangan Bisnis: Konsep dan Aplikasinya. Jakarta: Mitra Wacana Media.

Hamrita, M.E. dan Trifi, A. 2011. The Relationship between Interest Rate, Exchange Rate and Stock Price: A Wavelet Analysis: International Journal of Economics and Financial Issues. Vol.1, No. 4,Hal.220-228.

Husnan, S. dan Pudjiastuti, E. 2012. Dasar-Dasar Manajemen Keuangan. Edisi Keenam. Cetakan Pertama. Yogyakarta: UPP STIM YPKN.

Ismail. 2010. Manajemen Perbankan. Edisi Pertama. Jakarta: Kencana.

Kandir, S.Y. 2008. Macroeconomic Variables, Firm Characteristics and Stock Returns: Evidence from Turkey. International Research Journal of Finance and Economics.Issue 16, Hal. 35-45.

Karadeniz, E., Kandir, Y.S., Balcilar, M.dan Onal, B.Y. 2009. Determinants of Capital Structure: Evidence from Turkish Lodging Companies. International Journal of Contemporary HospitalityManagement. Vol. 21, No. 5, Hal.594-609.

Kewal, S.S. 2012. Pengaruh Inflasi, Suku Bunga, Kurs, dan Pertumbuhan PDB terhadap Indeks Harga Saham Gabungan. Jurnal Economia, Vol. 8, No. 1, Hal. 53-64.

Khalwaty, T. 2000. Inflasi dan Solusinya. Jakarta: PT. Gramedia Pustaka Utama.

Kusuma, J.T. 2016. Analisis Pengaruh Faktor Internal dan Faktor Eksternal Perrusahaan terhadap Nilai Perusahaan (Studi Empiris pada Perusahaan Manufaktur yang Terdaftar di Bursa Efek Indonesia Periode 2011-2014). Publikasi Ilmiah. Fakultas Ekonomi dan Bisnis Program Studi Akuntansi Universitas Muhammadiyah Surakarta.

Kusumaningrum, D.A.R. dan Rahardjo, S.N. 2013. Pengaruh Keputusan Investasi, Keputusan Pendanaan, Kebijakan Dividen, Kepemilikan Manajerial, dan Kepemilikan Institusional terhadap Nilai Perusahaan (Studi Empiris pada Perusahaan yang Terdaftar di Bursa Efek Indonesia Tahun 2011-2012). Diponegoro Journal of Accounting.Vol. 2, No. 4, Hal.1-10.

Levi, M.D. 2009. International Finance.Fifth Edition. New York: Routledge.

Liembono, R.H. 2016. Analisis Fundamental: Panduan Trading dan Investasi Saham. Surabaya: Brilliant.

Margaretha, F. 2013. Dasar-Dasar Manajemen Keuangan.Jakarta: Dian Rakyat.

Mishkin, F.S. 2008. Ekonomi Uang, Perbankan, dan Pasar Keuangan.Edisi 8. Buku 1. Jakarta: Salemba Empat. 
Momani, G.F. dan Alsharari, M.A. 2012. Impact of Economic Factors on the Stock Prices at Amman Stock Market (1992-2010). International Journal of Economics and Finance.Vol. 4, No. 1, Hal.151-159.

Mousa, S.N., Al safi, W., Hasoneh, A.B. dan Abo-orabi, M.M. 2012. The Relationship between Inflation and Stock Prices (A Case of Jordan).IJRRAS.Vol. 10, No. 1, Hal.46-52.

Noerirawan, M.R. dan Muid, A. 2012. Pengaruh Faktor Internal dan Eksternal Perusahaan terhadap Nilai Perusahaan (Studi Empiris pada Perusahaan Manufaktur yang Terdaftar di Bursa Efek Indonesia Periode 2007-2010). Diponegoro Journal of Accounting. Vol 1, No 1, Hal. 1-12.

Oshaibat, S. dan Majali, A. 2016.The Relationship between Stock Returns and Each of Inflation, Interest Rates, Share Liquidity and Remittances of Workers in the Amman Stock Exchange.Journal of Internet Banking and Commerce.Vol. 21, No. 2, Hal.1-18.

Prasetyo, P.E. 2011. Fundamental Makro Ekonomi. Edisi Kedua. Yogyakarta: Beta Offset.

Pratama, I.G.C.W. dan Wirawati, N.G.P. 2016.Pengaruh Struktur Modal dan Profitabilitasterhadap Nilai Perusahaan dengan Kepemilikan Manajerial sebagai Pemoderasi.E-Jurnal Akuntansi Universitas Udayana. Vol. 15, No. 3, Hal.1796-1825.

Rismawati, N.M. dan Dana, I.M. 2014.Pengaruh Pertumbuhan Aset dan Tingkat Suku Bunga Sertifikat Bank Indonesia (SBI) terhadap Kebijakan Dividen dan Nilai Perusahaan pada Perusahaan Manufaktur di Bursa Efek Indonesia (BEI).E-Jurnal Manajemen Universitas Udayana.Vol. 3, No. 4, April.

Salempang, E.L., Sondakh, J.J. dan Pusung, R.J. 2016. Pengaruh Return on Aseet, Debt to Equity dan Pertumbuhan Penjualan terhadap Nilai Perusahaan pada Sektor Real Estate dan Property yang Terdaftar di BEI Tahun 2013-2014. Jurnal Berkala Ilmiah Efisiensi. Vol.16, No.3. Hal. 813824.

Sartini, L.P.N. dan Purbawangsa, I.B.A. 2015.Pengaruh Keputusan Investasi, Kebijakan Dividen, serta Keputusan Pendanaan terhadap Nilai Perusahaan pada Perusahaan Manufaktur di Bursa Efek Indonesia.Matrik: Jurnal Manajemen, Strategi Bisnis dan Kewirausahaan. Vol. 3, No. 8, Hal. 81-90.

Sekaran, U. dan Bougie, R. 2013. Research Methods for Business: A Skill-Building Approach. Sixth Edition. New York: Wiley.

Setiani, R. 2013. Pengaruh Keputusan Investasi, Keputusan Pendanaan, dan Tingkat Suku Bunga terhadap Nilai Perusahaan pada Perusahaan Otomotif yang Terdaftar di Bursa Efek Indonesia. Jurnal Manajemen. Vol.2, No.1, Hal. 1-10.

Situmorang, H.S. dan Muslich, L. 2014.Analisis Data untuk Riset Manajemen dan Bisnis. Medan: USU Press.

Sugiyono. 2015. Statistika untuk Penelitian. Bandung: Alfabeta.

Suryantini, N.P.S. dan Arsawan, I.W.E. 2014. Pengaruh Faktor Eksternal terhadap Nilai Perusahaan (PBV) dan Harga Saham terhadap Perusahaan Manufaktur diBursa Efek Indonesia. Jurnal Manajemen, Strategi Bisnis dan Kewirausahaan. Vol.8, No.2, Hal. 91-100.

Suteja, J. dan Manihuruk, W. 2009. Pengaruh Struktur Modal, Kepemilikan, dan Faktor Eksternal pada Penentuan Nilai Perusahaan. Trikonomika. Vol.8, No.2, Hal. 78-89.

Tandelilin, E. 2010. Portofolio dan Investasi: Teori dan Aplikasi. Edisi 1. Yogyakarta: Kanisius.

Wijaya, I.R.P. dan Wibawa, A. 2010. Pengaruh Keputusan Investasi, Keputusan Pendanaan dan Kebijakan Dividen terhadap Nilai Perusahaan. Prosiding. Simposium Nasional Akuntansi XIII. Hal. 1-21.

Wongbangpo, P. dan Sharma, S.C. 2002. Stock Market and Macroeconomic Fundamental Dynamic Interaction: ASEAN-5 Countries. Journal of Asian Economics. Vol. 13, No. 1, Hal.27-51.

Zakaria, J. 2009. Pengantar Teori Ekonomi Makro. Jakarta: Gaung Persada (GP Press). 